\title{
TOKSISITAS PROTEIN 89 kDa PRODUK EKSTRASELULER Streptococcus agalactiae PADA IKAN NILA (Oreochromis niloticus)
}

\author{
Amrullah" "\#, Sukenda"), Enang Harris"), Alimuddin"'), dan Angela Mariana Lusiastuti" ${ }^{\left.*{ }^{* 0}\right)}$ \\ ") Politeknik Pertanian Negeri Pangkajene Kepulauan, Jurusan Budidaya Perikanan \\ ") Departemen Budidaya Perairan, Fakultas Perikanan dan Ilmu Kelautan, Institut Pertanian Bogor \\ m) Balai Penelitian dan Pengembangan Budidaya Air Tawar, Bogor
}

(Naskah diterima: 25 September 2014; Revisi final: 15 Juni 2015, Disetujui publikasi: 2 September 2015)

\begin{abstract}
ABSTRAK
Identifikasi protein toksin yang bersifat antigenik dari produk ekstraselular (ECP) crude Streptococcus agalactiae penting dilakukan untuk pengembangan vaksin protein toksoid. Penelitian ini bertujuan untuk mengevaluasi toksisitas protein dengan berat molekul 89 kDa dari ECP Streptococcus agalactiae hasil fraksinasi dengan SDS-PAGE (ECPP89). Ikan nila dengan bobot sekitar $25 \mathrm{~g}$ masing-masing diinjeksi secara intraperitonial dengan protein ECPP89 dosis 1, 2, 4, 8, dan $16 \mu \mathrm{g} / \mathrm{mL} / \mathrm{ekor}$ ikan (secara berturut-turut diberi kode ECPP89-1, ECPP89-2, ECPP89-4, ECPP89-8, dan ECPP89-16). Sebagai kontrol positif ikan diinjeksi dengan bakteri utuh S. agalactiae $1 \times 10^{4} \mathrm{cfu} / \mathrm{mL}$ (WCB) dan ECP crude S. agalactiae (ECPC), sementara kontrol negatif ikan diinjeksi larutan PBS. Ikan dipelihara selama 15 hari dengan kepadatan 10 ekor $(70 \mathrm{~L}$ air). Hasil penelitian menunjukkan bahwa ikan nila yang diinjeksi dengan ECPP89 mengalami gejala seperti perubahan morfologi, perubahan nafsu makan, dan perubahan renang ikan. Mortalitas pada perlakuan ECPP89 secara umum lebih tinggi dibandingkan dengan ECPC, namun lebih rendah $(\mathrm{p}<0,05)$ dibandingkan dengan WCB. Mortalitas ikan pada perlakuan ECPP89-4, ECPP89-8, dan ECPP89-16 tidak berbeda tetapi secara signifikan lebih tinggi dibandingkan dengan ECPC dan dua dosis perlakuan ECPP89 lainnya $(p<0,05)$. Ikan kontrol negatif tidak mengalami kematian maupun perubahan klinis. Hasil ini menunjukkan bahwa ECPP89 merupakan protein toksin dari ECP S. agalactiae.
\end{abstract}

KATA KUNCI: toksisitas, nila, Streptococcus agalactiae, produk ekstraselular

ABSTRACT: Toxicity of the 89 kda protein, an extracellular products of Streptococcus agalactiae, on nile tilapia (Oreochromis niloticus). By: Amrullah, Sukenda, Enang Harris, Alimuddin, and Angela Mariana Lusiastuti

The identification of antigenic protein toxins which are derived from Streptococcus agalactiae crude extracellular products $(E C P)$ is very important in the development of the toxin protein vaccine. This study's purpose was to evaluate the toxicity of the protein with a molecular weight of $89 \mathrm{kDa}$ from Streptococcus agalactiae ECP, produced through fractionation using SDS-PAGE (ECPP89). Nile tilapia weighing approximately of $25 \mathrm{~g}$ each were injected intraperitoneally with ECPP89 protein at doses of 1, 2, 4, 8, and $16 \mu \mathrm{g} / \mathrm{mL} / \mathrm{fish}$ (coded by ECPP89-1, ECPP89-2, ECPP89-4, ECPP89-8, and ECPP89-16, respectively). The positive control fishes were injected with $1 \times 10^{4} \mathrm{cfu} / \mathrm{mL}$ S. agalactiae whole-cell bacteria (WCB) and S. agalactiae crude ECP (ECPC). The negative control fishes were injected with PBS solution. The fish were kept for 15 days at a density of 10 individuals/70 L water. The results of this study showed that nile tilapia injected with ECPP89 demonstrated specific signs of S. agalactiae infection such as changes in external anatomy, loss appetite, and changes in swimming patterns. The mortality in the ECPP89 treatment was generally higher $(p<0.05)$ than the ECPC treatment, but it was lower than the WCB treatment. Fish mortality in ECPP89-4, ЕСРP89-8, and ЕСРP89-16 treatments were not distinct but it were significantly higher than in ECPC and the other two dosages of ECPP89 $(p<0.05)$. The negative control fish did not die or demonstrate clinical changes. This suggests that ECPP89 is a toxin ECP protein of S. agalactiae.

KEYWORDS: $\quad$ toxicity, nile tilapia, Streptococcus agalactiae, extracellular products

\# Korespondensi: Politeknik Pertanian Negeri Pangkajene Kepulauan, Jurusan Budidaya Perikanan. Jl. Poros Makassar-Pare Km. 83, Kecamatan Mandalle Kabupaten Pangkep, Sulawesi Selatan 90655, Indonesia. Telp. (0410) 2312704

E-mail: ulla_285@yahoo.com 


\section{PENDAHULUAN}

Salah satu jenis penyakit yang sering menyerang ikan dengan tingkat virulensi yang tinggi terutama pada ikan nila adalah penyakit streptococcosis yang disebabkan oleh bakteri Streptococcus agalactiae. Tingkat virulensi bakteri yang tinggi ditentukan oleh kemampuan bakteri menghasilkan toksin yang merupakan mekanisme penting pada hampir semua bakteri patogen penyebab penyakit. Toksin merupakan zat racun yang dibentuk dan dikeluarkan oleh organisme yang dapat menyebabkan kerusakan radikal dalam struktur, merusak total hidup atau keefektifan organisme lain pada satu bagian. Toksin yang berasal dari bakteri adalah komponen racun terlarut yang diproduksi oleh bakteri dan menyebabkan pengaruh negatif terhadap sel-sel inang dengan cara mengubah metabolisme normal dari sel inang tersebut. Toksin yang berhubungan dengan sel bakteri disebut sebagai endotoksin, sedangkan toksin yang dapat berdifusi secara ekstraselular disebut sebagai eksotoksin. Eksotoksin biasanya protein yang bertindak secara enzimatik atau bertindak secara langsung pada sel inang dan merangsang berbagai respons inang (Todar, 2012).

Toksisitas bakteri ditandai dengan proses lisosomal yang tidak stabil, fagositosis yang tidak berhasil dan perubahan fungsi fagositosis sel. Hal ini menyebabkan kemampuan hewan untuk mempertahankan diri terhadap patogen dan penyakit menular secara signifikan berkurang (Jovanovi \& Pali, 2012). Meskipun mekanisme patogenik bakteri belum diketahui dengan tepat (Wang et al., 2010); namun beberapa faktor virulensi bakteri seperti protein eksotoksin dapat mematikan host melalui aktivitas protease, dermatotoxin, hemolisin, siderophore, dan resistensi terhadap fagosit (Suprapto et al., 1996).

Toksin yang merupakan produk ekstraseluler ( $E x$ tracellular product/ECP) dihasilkan oleh bakteri $S$. agalactiae merupakan komponen protein terlarut yang disekresikan oleh bakteri pada fase pertumbuhan eksponensial yang berfungsi seperti enzim dan memiliki sifat-sifat enzim yaitu terdenaturasi oleh panas, asam, dan enzim proteolitik dengan potensi toksik yang tinggi dan bersifat antigenik. Apabila masuk ke dalam tubuh inang maka toksin akan menyebabkan kerusakan radikal dalam struktur, merusak total hidup atau keefektifan organisme lain pada satu bagian. Toksin yang dapat berdifusi secara ekstraselular disebut eksotoksin, biasanya merupakan protein yang bertindak secara enzimatik atau bertindak secara langsung pada sel inang dan merangsang berbagai respons inang (Todar, 2012).

Pengembangan vaksin dari toksin protein dimulai dengan mengidentifikasi protein yang bersifat antigenik dalam ECP crude dengan cara menguji toksisitas protein hasil fraksinasi yang memiliki berat molekul berbeda. Salah satu protein yang telah difraksinasi dari ECP S. agalactiae adalah protein dengan berat molekul $89 \mathrm{kDa}$. Penelitian ini bertujuan mengevaluasi toksisitas protein dengan berat molekul 89 kDa dari ECP S. agalactiae hasil fraksinasi dengan SDS-PAGE pada ikan nila.

\section{BAHAN DAN METODE}

\section{Isolasi ECP}

ECP diisolasi dari bakteri S. agalactiae tipe nonhemolitik $\mathrm{N}_{14} \mathrm{G}$ koleksi Balai Penelitian dan Pengembangan Budidaya Air Tawar Bogor, Kementerian Kelautan dan Perikanan. Isolat uji diinokulasikan dalam media brain hearth infussion agar (BHIA) berdasarkan Hardi (2011). Isolasi ECP berdasarkan pada pola pertumbuhan populasi maksimal, yaitu 72 jam pascainokulasi pada media BHI (Evans et al., 2004). Supernatan yang berisi ECP diaduk menggunakan shaker kemudian disaring dengan filter miliphore steril 0,22 $\mu \mathrm{m}$ (membran solution MS ${ }^{\circledR} C A$ syringe filter) dan disimpan pada suhu $-20^{\circ} \mathrm{C}$ hingga akan digunakan.

\section{Fraksinasi Protein Produk ECP Bakteri $S$. agalactiae}

Fraksinasi protein dilakukan dengan metode SDSPAGE (Laemmli, 1970). Sebelum dilakukan fraksinasi, terlebih dahulu dilakukan pemekatan konsentrasi ECP dengan menggunakan vivaspin konsentrator sentrifugal $6 \mathrm{~mL}$ (vivaspin centrifugal concentrator, GE Healthcare Bio-Sciences AB Björkgatan 3075184 Uppsala Sweden) yang disentrifugasi pada $12.500 \mathrm{rpm}$ pada suhu $4^{\circ} \mathrm{C}$. Sebanyak $20 \mathrm{~mL}$ ECP crude dipekatkan dengan vivaspin hingga diperoleh ECP pekat sebanyak $1 \mathrm{~mL}$. Hasil pemekatan ECP sebanyak $100 \mu \mathrm{L}$ dilarutkan dalam $50 \mu \mathrm{L}$ buffer, kemudian diseparasi menggunakan SDS-PAGE dengan konsentrasi gel 12\% dan tebal $1,5 \mathrm{~mm}$. Gel diwarnai dengan silver staining dan kemudian dijadikan pola untuk memotong gel akrilamid.

\section{Isolasi Protein dari Gel Acrylamid}

Isolasi protein toksoid dari hasil fraksinasi gel acrylamid SDS-PAGE dilakukan dengan electro-eluter (Biorad). Hasil elektroforesis SDS-PAGE dan pewarnaan silver staining menunjukkan tiga pita protein dengan berat molekul 76,52 kDa; $89 \mathrm{kDa}$; dan 132,92 kDa (Gambar 1). Pita dengan berat molekul 89 kDa dipotong kecil dan dimasukkan ke glass tube yang telah terpasang pada modul. Elusi dilakukan pada 8$10 \mathrm{~mA} / \mathrm{glass}$ tube selama 3-5 jam. Setelah proses elusi, modul elektro eluter dikeluarkan dari chamber, glass tube dikeluarkan dari modul. Protein di dalam sili- 


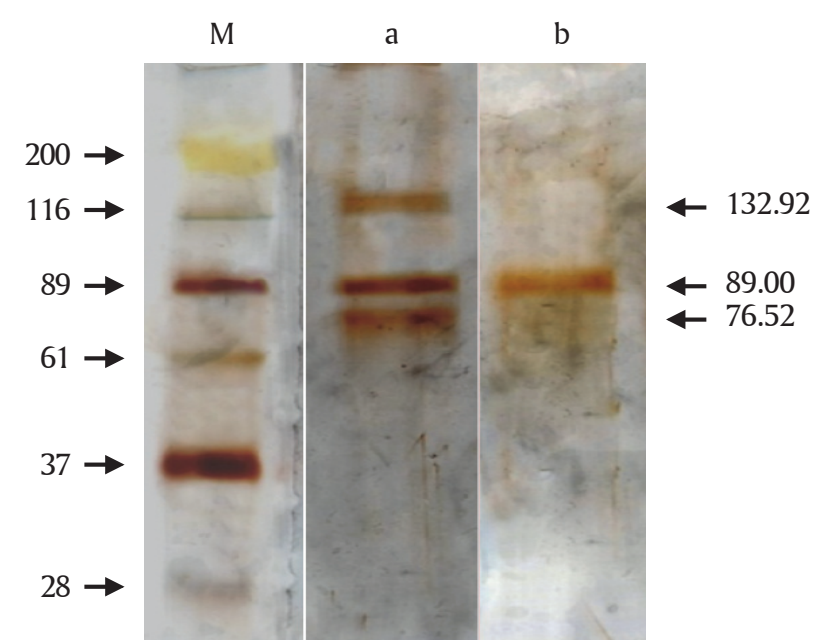

Gambar 1. Fraksinasi dengan metode SDS-PAGE protein toksin dari ECP bakteri Streptococcus agalactiae yang dipekatkan dengan vivaspin; (a) pita protein dengan berat molekul 76,52 kDa; 89 kDa; dan 132,92 $\mathrm{kDa}$; (b) hasil isolasi dan pemurnian protein 89 kDa dengan electroeluter; (M) marker

Figure 1. Fractionated using SDS-PAGE protein toxin from the bacteria Streptococcus agalactiae ECP were concentrated by vivaspin; (a) protein bands with molecular weight of 76.52 $k D a, 89 k D a$, and $132.92 \mathrm{kDa}$; (b) the results of the isolation and purification of the $89 \mathrm{kDa}$ protein with electroeluter; (M) the marker

kon diambil dan dimasukkan ke dalam eppendorf sebagai protein murni $89 \mathrm{kDa}$ dan disimpan pada suhu $-20^{\circ} \mathrm{C}$ untuk analisis lebih lanjut.

\section{Pengujian Protein ECP dan Pemeliharaan Ikan}

Ikan dengan bobot sekitar $25 \mathrm{~g}$ ekor $^{-1}$ dipelihara pada akuarium berukuran $60 \mathrm{~cm} \times 30 \mathrm{~cm} \times 40 \mathrm{~cm}$ dengan kepadatan 10 ekor/akuarium. Jenis protein yang diujikan adalah protein hasil fraksinasi dari ECP S. agalactiae dengan berat molekul $89 \mathrm{kDa}$ dengan dosis $1,2,4,8,16 \mu \mathrm{g} / \mathrm{mL} /$ ekor ikan (secara berturutturut diberi kode ECPP89-1, ЕСРP89-2, ЕСРP89-4, ECPP89-8, dan ECPP89-16). Pengenceran protein sesuai dosis perlakuan dilakukan dengan menggunakan PBS dan diukur konsentrasinya dengan Nanodrop 2.000 (Spectrophotometer thermo scientific) dengan absorbansi 1 pada $280 \mathrm{~nm}$. Dua kontrol positif terdiri atas bakteri utuh $S$. agalactiae $1 \times 10^{4} \mathrm{cfu} / \mathrm{mL}$ (WCB) dan ECP crude bakteri S. agalactiae (ECPC) dan satu kontrol negatif dengan menggunakan larutan PBS. Ikan diinjeksi secara intraperitonial (i.p.) 0,1 mL/ekor ikan sesuai perlakuan. Selanjutnya ikan dipelihara selama 15 hari dan dilakukan pengamatan gejala kli- nis ikan, perubahan tingkah laku renang dan makan, serta mortalitas ikan. Ikan yang menunjukkan gejala klinis terinfeksi S. agalactiae dijadikan sampel untuk pengamatan histologi dari organ mata, ginjal, dan otak. Ikan yang mati dihitung untuk mengetahui persentase mortalitas.

\section{Analisis Data}

Penelitian dilakukan dengan menggunakan rancangan acak lengkap. Data mortalitas ikan dianalisis secara statistik pada taraf $\mathrm{p}<0,05$ (dua arah) menggunakan program SPSS 17 for Windows. Apabila terdapat pengaruh perlakuan, maka digunakan uji lanjut Duncan.

\section{HASIL DAN BAHASAN}

\section{Perubahan Anatomi Luar, Pola Renang, dan Tingkah Laku Makan}

Hasil pengujian patogenitas protein toksin dengan pemaparan secara i.p. ditampilkan pada Gambar 2. Perubahan pada ikan setelah pemaparan protein terjadi pada hari ke-3, di mana beberapa ekor ikan mulai menunjukkan perubahan warna badan menjadi gelap pada perlakuan ECPP89-4, ECPP89-8, ECPP89-16, ECPP, dan WCB. Selanjutnya pada hari ke-4, ikan yang sebelumnya telah berwarna gelap mengalami clear operculum dan menunjukkan pengerutan mata sehingga terlihat mata hitam ikan menjadi kecil. Pada tahap selanjutnya terjadi eksoptalmia dan badan ikan berbentuk huruf C. Perubahan organ luar ikan ini terjadi pada perlakuan ECPP-2, ECPP89-4, ECPP89-8, ECPP89-16, ECPC, dan WCB, tetapi tidak terjadi pada perlakuan ECPP89-1 dan kontrol PBS.

Perubahan pola renang ikan terjadi pada hari ketiga pasca injeksi di mana ikan diam dan soliter di dasar akuarium pada perlakuan ECPP89-4, ECPP89-8, ECPP89-16, dan WCB. Perubahan pola renang tersebut terjadi pada perlakuan ECPC dan ECPP89-2 setelah hari kelima, sedangkan kontrol negatif PBS tidak mengalami perubahan pola renang. Kelainan pola renang berupa gerak berputar (whirling) terjadi pada hari ke-7 pasca penginfeksian pada perlakuan ECPP 89-4, ECPP89-8, ECPP89-16, dan WCB; dan hari ke-8 pada perlakuan ECPC.

Pola tingkah laku makan berupa penurunan nafsu makan ikan tidak mengalami perubahan selama 48 jam pascainfeksi. Perubahan tingkah laku makan terjadi pada hari ketiga bersamaan dengan terjadinya perubahan warna ikan menjadi gelap, terjadinya pengerutan mata, dan eksopthalmia pada perlakuan ECPP89-4, ЕCPP89-8, ECPP89-16, WCB, dan ECPC, tetapi pola tingkah laku makan ikan tidak terjadi pada perlakuan ECPP89-1 dan PBS. 

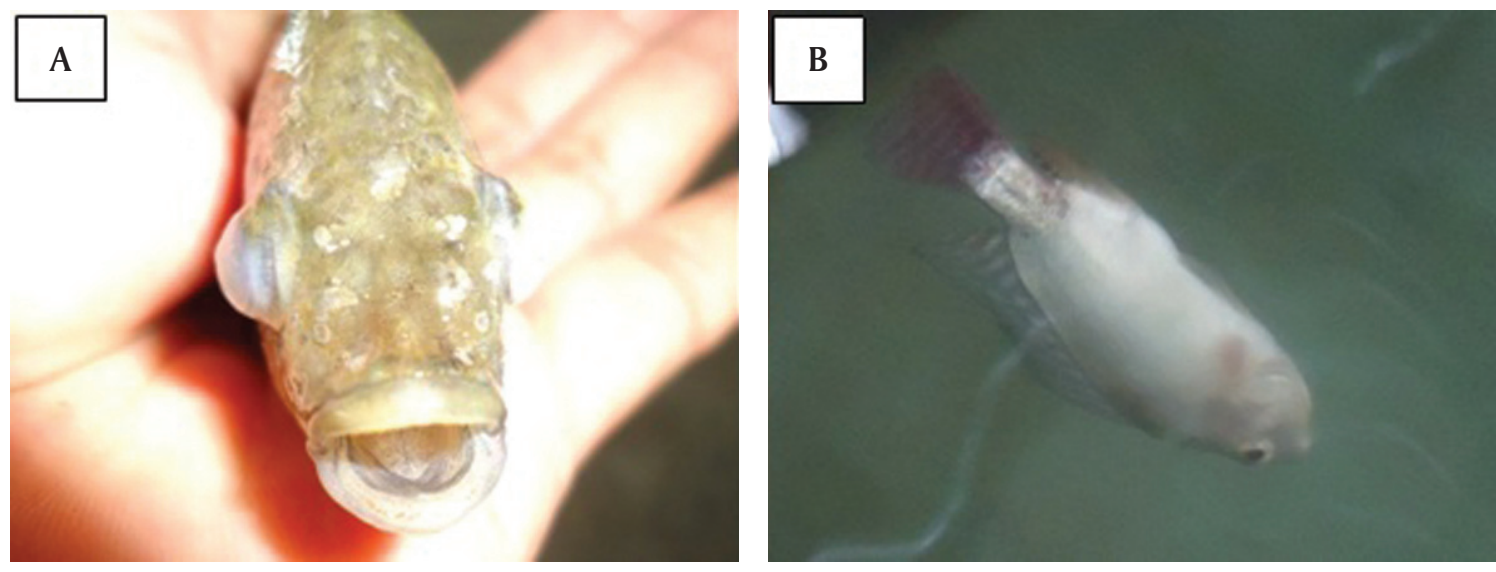

Gambar 2. Perubahan performasi morfologi ikan nila (O. niloticus) berupa (A) eksopthalmia dan (B) whirling setelah diinjeksi dengan ECPP89

Figure 2. Changes in nile tilapia's (O. niloticus) external morphology, i.e. (A) exopthalmia and (B) whirling after being injected with ECPP89

Evaluasi toksisitas protein dari fraksinasi ECP $S$. agalactiae menunjukkan bahwa ECPP89 terutama ECPP89-4, ECPP89-8 ECPP89-16, bersifat toksik dengan menyebabkan terjadinya perubahan morfologi, perubahan pola renang dan makan, serta kematian ikan nila. Pada perlakuan ECPP89-1 tidak dapat menyebabkan perubahan pada ikan karena dosis protein yang rendah. Perubahan gejala klinis, pola renang, dan pola makan setelah pemaparan ECPP89 sama dengan gejala klinis yang terjadi pada ikan nila yang dipapar dengan WCB dan ECPP, namun gejala klinis di atas tidak terjadi pada ikan yang diinjeksi dengan PBS. Hasil penelitian ini mendukung penelitian sebelumnya di mana ikan yang terserang S. agalactiae menunjukkan septicaemia kolonisasi sejumlah organ seperti nares, otak, ginjal, dan usus; gejala klinis setelah terjadi infeksi seperti anorexia, C-shaped, erratic swimming, whirling, dan mati (Evans et al., 2002). Ikan nila yang dibudidayakan di karamba dan terinfeksi bakteri Streptococcus menunjukkan gejala klinis dengan berenang tidak menentu dan whirling, penurunan nafsu makan, unilateral atau bilateral eksoptalmia sebagai gejala klinis utama (Salvador et al., 2005). Ikan kontrol yang diinfeksi dengan Streptococcus agalactiae menunjukkan perubahan dengan gejala klinis seperti anoreksia, lesu, berenang tidak menentu, exophthalmia, dan ascites.

\section{Mortalitas Ikan}

Mortalitas ikan nila setelah penginfeksian bervariasi berdasarkan perlakuan (Tabel 1). Mortalitas ikan yang diinjeksi secara i.p. dengan perlakuan ECPP894, ECPP89-8, ECPP89-16 secara signifikan lebih tinggi $(\mathrm{p}<0,05)$ dibandingkan dengan perlakuan protein ECPP89-2, ECPP89-1, ECPC, dan PBS. Mortalitas ikan antara perlakuan ECPP89-4, ECPP89-8, ECPP89-16 ti-
Tabel 1. Mortalitas ikan nila (Oreochromis niloticus) setelah diinjeksi secara i.p. (intraperitoneal) dengan ECPP89 sebanyak 0,1 mL/ekor ikan

Table 1. The mortality rate of nile tilapia (Oreochromis niloticus) after being injected with $0.1 \mathrm{~mL} /$ fish ECPP89 intraperitoneally

\begin{tabular}{cc}
\hline Perlakuan (Treatments) & Mortalitas (Mortality) (\%) \\
\hline ECPP89-1 & $0^{\mathrm{d}}$ \\
ECPP89-2 & $5^{\mathrm{d}}$ \\
ECPP89-4 & $35^{\mathrm{b}}$ \\
ECPP89-8 & $40^{\mathrm{b}}$ \\
ECPP89-16 & $35^{\mathrm{b}}$ \\
WCB & $55^{\mathrm{a}}$ \\
ECPC & $20^{\mathrm{c}}$ \\
PBS & $0^{\mathrm{d}}$ \\
\hline
\end{tabular}

Keterangan (Note):

Huruf superskrip yang berbeda pada kolom yang sama menunjukkan perbedaan yang signifikan $(\mathrm{p}<0,05)$ (Different superscript in the same column show the significantly different $(p<0.05))$

dak berbeda nyata $(p>0,05)$, namun lebih rendah dibandingkan dengan WCB $(\mathrm{p}<0,05)$.

Kelainan patologi yang terjadi pada ikan nila diinjeksi dengan ECPP89 pada akhirnya mengalami kematian. Gejala ini sama dengan ikan yang diinjeksi dengan WCB, dan ECPP meskipun dengan persentase mortalitas berbeda. Hal ini menunjukkan bahwa ECPP89 merupakan protein toksik yang tidak hanya menginfeksi ikan seperti pada penjelasan di atas, tetapi juga menyebabkan kematian pada ikan nila. Hasil penelitian ini menunjukkan bahwa ECP ikut menentukan virulensi bakteri $S$. agalactiae yang disekresikan oleh bakteri. Protein dalam eksotoksin yang 
bertanggung jawab terhadap virulensi ini adalah protein dengan berat molekul $89 \mathrm{kDa}$. Hal ini terbukti dengan persamaan kelainan patologi yang diakibatkan antara perlakuan WCB, ECPP, dan ECPP89.

Protein toksin yang disekresikan oleh bakteri hidup pada masa pertumbuhan eksponensial merupakan penentu utama virulensi. Lokasi kerusakan yang disebabkan oleh toksin menunjukkan lokasi target toksin yang spesifik. Namun beberapa jenis toksin memiliki aktivitas sitotoksik yang cukup luas dan menyebabkan kematian non-spesifik dari berbagai jenis sel atau kerusakan jaringan, dan pada akhirnya mengakibatkan nekrosis (Todar, 2012).

Karakterisasi lebih lanjut faktor penentu virulensi dalam ECPP89 pada penelitian ini belum diketahui. Namun menurut Pasnik et al. (2005), virulensi dari streptococcal ditentukan oleh komponen galactose dan asam sialik. Sedangkan pada ECP bakteri $A$. hydrophila, terdiri atas metalloproteases, glycerophospholipidcholesterol acyltransferase, hemolysin, aerolysin, dan lipases, juga protein untuk pencernaan seperti amylases and chitinases, serta protein untuk perlekatan pada sel inang seperti S-layer dan flagella yang seluruhnya berperan penting pada distribusi, adaptasi, dan patogenisitas (Zhang et al., 2014). Faktor virulensi pada patogenesis E. tarda di antaranya adalah dermatotoxin (Ullah et al., 1983), hemolisis (Hirono et al., 1997), kemampuan untuk menyerang sel-sel epitel (Ling et al., 2000) dan kemampuan bertahan dalam fagosit (Srinivasa et al., 2003). Faktor virulensi pada whole-cell S. iniae adalah enolase (EN), glyceraldehyde-3-phosphate dehydrogenase (GAPDH), dan fructose-bisphosphate aldolase (FBA) (Shin et al., 2007) yang dapat bersifat imunogenik.

Bakteri yang melibatkan ECP dalam virulensinya telah banyak diteliti, di antaranya toksin dalam ECP A. hydrophila dapat mematikan ikan nila (Khalil \& Mansour, 1997), ikan rohu (Sahu et al., 2011), dan ikan lele (Pridgeon et al., 2013); toksin dengan berat molekul $37 \mathrm{kDa}$ dalam ekstraseluler dan intraseluler $E$. tarda mematikan Japanese eel and Japanese flounder (Suprapto et al., 1996), toksin NUF251 dari ECP E. tarda yang sangat virulen (Wang et al., 2010).

Mekanisme masuknya toksin bakteri S. agalactiae ke dalam sel ikan, khususnya ikan nila belum dipelajari. Namun menurut (Todar, 2012), setidaknya terdapat dua mekanisme masuknya toksin ke dalam sel target yang diperankan oleh active component disebut sub unit A dan binding component disebut sub unit B. Mekanisme pertama adalah toksin masuk langsung, di mana sub unit B dari toksin asal $(A+B)$ melekat pada reseptor spesifik pada sel target dan menginduksi pembentukan lubang pada membran sel inang di mana melalui lubang tersebut sub unit A ditrans- fer ke dalam sitoplasma sel. Mekanisme kedua, toksin mengikat sel target dan struktur A + B dilepaskan ke dalam sel melalui receptor-mediated endocytosis (RME) yang dimediasi oleh endositosis. Toksin dimasukkan ke dalam endosom. Ion $\mathrm{H}^{+}$masuk ke dalam endosom menurunkan $\mathrm{pH}$ internal yang menyebabkan sub unit A + B memisah. Sub unit B memengaruhi pelepasan sub unit $A$ dari endosom sehingga akan mencapai target dalam sitoplasma sel. Sub unit B tetap dalam endosom dan dapat kembali ke permukaan sel. Pada kedua kasus di atas, sebuah molekul protein besar harus masuk dan melintasi membran lipid bilayer, baik membran sel atau membran endosome.

Toksin yang telah masuk ke dalam tubuh organisme secara umum akan dapat mengaktifkan mekanisme pertahanan imun alami. Dalam kebanyakan kasus termasuk ikan dan mamalia, tanggap kebal ini dimediasi oleh makrofag melalui produksi berbagai mediator seperti nitric oxide (NO), reactive oxygen species (ROS), dan proinflammatory cytokines (misalnya TNF$\alpha)$ (Wang et al., 2010).

\section{Histopatologi}

Berdasarkan hasil histopatologi ikan yang diinjeksi dengan ECPP89 mengalami perubahan patologi pada otak, mata, dan ginjal yaitu terjadinya vacuolisis, kongesti, nekrosa, hemorhagik, melanomacrofag centre (MMC), dan infiltrasi sel radang. Pada otak ikan terjadi gangguan aliran darah (kongesti/pembendungan), vakuolisis, hemorhagik, dan nekrosis (Gambar 3A). Kelainan histologi pada ginjal di antaranya adalah MMC, infiltrasi sel radang, dan nekrosis (Gambar 3B), sedangkan pada mata hanya ditemukan vakuolisis (Gambar 3C).

Histopatologi ikan setelah diinjeksi dengan ECPP89 terjadinya kongesti (pembendungan) pada pembuluh darah yaitu meningkatnya jumlah darah dalam pembuluh yang ditunjukkan dengan kapiler darah tampak melebar yang penuh berisi eritrosit. Kongesti dapat terjadi akibat adanya reaksi peradangan akibat trauma, toksin atau mikroorganisme. Menurut Smith et al. (1972), kongesti merupakan pembendungan darah di dalam pembuluh darah di mana secara mikroskopik terlihat pembuluh kapiler dan vena berdilatasi dan berisi darah. Kongesti menyebabkan pembuluh darah melebar dengan aliran darah yang melambat. Hal ini mengakibatkan darah membendung di jaringan sehingga berkumpul membentuk pembendungan di pembuluh darah. Pada kasus kongesti yang berlebihan akan dapat menimbulkan perdarahan, sehingga cairan akan bercampur dengan sel darah merah. Kongesti dapat berlanjut menjadi edema sehingga serabut otot akan tampak menjadi jarang karena rongga antar serabutnya berisi cairan. 

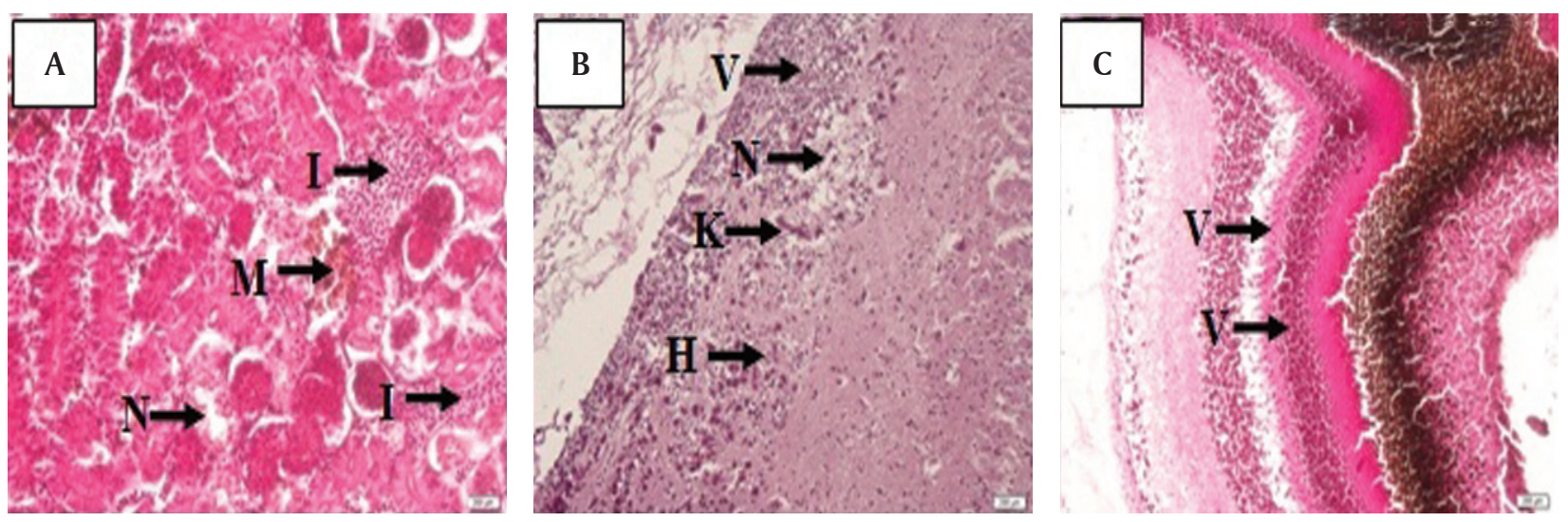

Gambar 3. Perubahan histologi ikan nila (Oreochromis niloticus) setelah diinjeksi dengan ECPP89 kDa. Organ ginjal (A), otak (B) dan mata (C). V (vakuolisis), K (kongesti), N (nekrosis), H (hemorhagik), M (Melanomacrofag Centre/MMC) dan I (infiltrasi sel radang)

Figure 3. Histological changes in nile tilapia (Oreochromis niloticus) after being injected with ECPP89 kDa. The kidney (A), brain (B) and eyes (C). $V$ (vacuolysis), $K$ (congestion), $N$ (necrosis), $H$ (hemorrhagic), $M$ (Melanomacrofag Centre/MMC) and I (infiltration of inflammation cells)

Pemaparan ECPP89 pada penelitian ini menyebabkan hemorhagik yang secara langsung disebabkan oleh adanya toksin protein dan secara tidak langsung oleh defisiensi nutrien karena nafsu makan ikan yang rendah sebagai akibat dari terjadinya perubahan organ tubuh. Hemorhagik ditandai dengan keluarnya darah dari pembuluh darah, baik keluar tubuh maupun di jaringan atau rongga tubuh (Smith et al., 1972). Hemorhagik dapat mengakibatkan suplai darah terganggu sehingga pada akhirnya akan terjadi nekrosa.

Kerusakan yang terdapat dalam jaringan otak ikan nila menyebabkan terjadinya pelemahan syaraf pada otak sehingga ikan berenang memutar (whirling) dan perubahan tingkah laku lainnya, serta penurunan nafsu makan. Apabila kerusakan terjadi pada syaraf motorik dapat mengakibatkan terganggunya syaraf yang mengontrol pergerakan dan keseimbangan ikan dalam berenang, sehingga terjadi perubahan renang ikan menjadi whirling (Murdjani, 2002), yang pada akhirnya menyebabkan ikan mati.

Perubahan sel lainnya adalah degenerasi dan nekrosis di mana sel lisis dan terlihat berlubang. Toksin secara langsung dapat menyebabkan degenerasi dan nekrosis sel dan secara tidak langsung disebabkan oleh ketidakseimbangan nutrisi. Degenerasi dan nekrosis sel otot dapat disebabkan oleh kekurangan dari material esensial (misalnya, oksigen atau asam pantotenat), kekurangan sumber energi yang mengganggu metabolisme, pemanasan mekanik atau luka akibat listrik, akumulasi subtansi yang abnormal di dalam sel-sel yang disebabkan oleh virus, bakteri, parasit, bahan kimia beracun, ketidakseimbangan nutrisi, dan zat-zat iritan ringan (Feist, 2003).

\section{KESIMPULAN}

Protein ECPP89 merupakan protein toksin yang secara signifikan menyebabkan perubahan morfologi, pola renang, makan, dan histopatologi, serta mortalitas ikan nila.

\section{DAFTAR ACUAN}

Evans, J.J., Klesius, P.H., Glibert, P.M., Shoemaker, C.A., Al-Sarawi, M.A., Landsberg, J., Duremdez, R., Al Marzouk, A., \& Al-Zenki, S. (2002). Characterization of beta-haemolytic group B Streptococcus agalactiae in cultured seabream, Sparus auratus L., and wild mullet, Liza klunzingeri (day), in Kuwait. J. Fish Dis., 25, 505-513.

Evans, J.J., Klesius, P.H., Shoemaker, C.A., \& Fitzpatrick, B.T. (2004). Streptococcus agalactiae vaccination and infection stress in nile tilapia, Oreochromis niloticus. J. Applied Aquaculture, 16, 10515.

Feist, S., Thain, J., \& Förlin, C. (2003). Molecular or cellular process and the health of the individual. p. 147-152. In Lawrence, A.J., \& Hemingway, K.L. (Eds.). Effects of Pollution on Fish. Blackwell Publishing. UK.

Hardi, E.H. (2011). Kandidat vaksin potensial Streptococcus agalactiae untuk mencegah penyakit Streptococcosis pada ikan nila (Oreochromis niloticus). Disertasi. Sekolah pascasarjana. Institut Pertanian Bogor. Bogor.

Hirono, I., Tange, N., \& Aoki, T. (1997). Iron-regulated haemolysin gene from Edwardsiella tarda. Mol. Microbiol., 24, 851-6.

Jovanovi, B., \& Pali, D. (2012). Immunotoxicology of non-functionalized engineered nanoparticles in 
aquatic organisms with special emphasis on fishReview of current knowledge, gap identification, and call for further research. Aquatic Toxicology, 118$119,141-151$.

Khalil, A.H., \& Mansour, E.H. (1997). Toxicity of crude extracellular products of Aeromonas hydrophila in tilapia, Tilapia nilotica. Lett. Appl. Microbiol., 25, 26973.

Laemmli, U.K. (1970). Cleavage of structural protein during the assembly of the head of bacteriophage T4. Nature, 227, 680-685.

Ling, S.H.M., Wang, X.H., Xie, L., Lim, T.M., \& Leung, K.Y. (2000). Use of green fluorescent protein (GFP) to study the invasion pathways of Edwardsiella tarda in in vivo and in vitro fish models. Microbiology, 146, 7-19.

Murdjani, M. (2002). Identifikasi dan patologi bakteri Vibrio alginolyticus pada ikan kerapu tikus (Cromileptes altivelis). Disertasi. Program Pasca Sarjana. Universitas Brawijaya. Malang.

Pasnik, D.J., Evans, J.J., Panangala, V.S., Klesius, P.H., Shelby, R.A., \& Shoemaker, C.A. (2005). Antigenicity of Streptococcus agalactiae extracellular products and vaccine efficacy. J. Fish Dis., 28, 205212.

Pridgeon, J.W., Klesius, P.H., Song, L., Zhang, D., Kojima, K., \& Mobley, J.A. (2013). Identification, virulence, and mass spectrometry of toxic ECP fractions of west Alabama isolates of Aeromonas hydrophila obtained from a 2010 disease outbreak. Vet. Microbiol, 164, 336-43.

Sahu, I., Das, B.K., Marhual, N., Samanta, M., Mishra, B.K., \& Eknath, A.E. (2011). Toxicity of crude extracellular products of Aeromonas hydrophila on rohu, Labeo rohita (Ham.). Indian J. Microbiol., 51, 515-20.

Salvador, R., Muiller, E.E., Freitas, J.C., Leonhadt, J.H., Pretto-Giordano, L.G., \& Dias, J.A. (2005). Isola- tion and characterization of Streptococcus spp. group $\mathrm{B}$ in nile tilapia Oreochromis niloticus reared in hapas nets and earth nurseries in the northern region of Parana State, Brazil. Ciência Rural, 35, 13741378.

Shin, G.W., Palaksha, K.J., Kim, Y.R., Nho, S.W., Kim, S., Heo, G.J., Park, S.C., \& Jung, T.S. (2007). Application of immunoproteomics in developing a Streptococcus iniae vaccine for olive flounder (Paralichthys olivaceus). J Chromatogr. B. Analyst. Technology Biomedical Life Sci., 849(1-2), 315-22.

Smith, H.A., Jones, T.C., \& Hunt, R.D. (1972). Veterinary pathology. Ed ke-4. Philadelphia. United States of America Press.

Srinivasa, R.P.S., Yamada, Y., \& Leung, K.Y.A. (2003). Major catalase (KatB) that is required for resistance to $\mathrm{H}_{2} \mathrm{O}_{2}$ and phagocyte-mediated killing in Edwardsiella tarda. Microbiology, 149, 2635-44.

Suprapto, H., Hara, T., Nakai, T., \& Muroga, K. (1996). Purification of a lethal toxin of Edwardsiella tarda. Fish Pathol., 31, 203-7.

Todar, K. (2012). Bacterial protein toxins. Todar's online textbook of bacteriology. Madison, Wiscon$\sin$.

Ullah, M.A., \& Arai, T. (1983). Exotoxic substances produced by Edwardsiella tarda. Fish Pathol., 2, 715.

Wang, Y., Osatomi, K., Yoshida, Y., Liang, X., Kanai, K., Oda, T., \& Hara, K. (2010). Extracellular products from virulent strain of Edwardsiella tarda stimulate mouse macrophages (RAW264.7) to produce nitric oxide (NO) and tumor necrosis factor (TNF)- $\alpha$. Fish Shellfish Immunol., 29, 778-785.

Zhang, D., Pridgeon, J.W., \& Klesius, P.H. (2014). Vaccination of channel catfish with extracellular products of Aeromonas hydrophila provides protection against infection by the pathogen. Fish Shellfish Immunol., 36, 270-275. 